\title{
Incidence, Severity and Gravity of Cassava Mosaic Disease in Savannah Agro-Ecological Region of DR-Congo: Analysis of Agro-Environmental Factors
}

\author{
Marcel Muengula-Manyi ${ }^{1}$, Kabwe K. Nkongolo ${ }^{2 *}$, Claude Bragard ${ }^{3}$, Patrick Tshilenge-Djim ${ }^{1}$, \\ Stephan Winter ${ }^{4}$, Adrien Kalonji-Mbuyi ${ }^{1,5}$ \\ ${ }^{1}$ Unit of Phytopathology, Faculty of Agronomy, University of Kinshasa, Kinshasa, Democratic Republic of Congo; ${ }^{2}$ Department of \\ Biology, Laurentian University, Sudbury, Canada; ${ }^{3}$ Earth and Life Institute, Applied Microbiology-Phytopathology, Université Ca- \\ tholique de Louvain, Louvain-la-Neuve, Belgium; ${ }^{4}$ Plant Virus Collection, DSMZ Deutsche Sammlung von Mikroorganismen und \\ Zellkuturen GmbH, Braunschweig, Germany; ${ }^{5}$ Nuclear Energy Center, Kinshasa (CRENK), Kinshasa, Democratic Republic of \\ Congo. \\ Email: *knkongolo@laurentian.ca
}

Received December $16^{\text {th }}$, 2011; revised January $13^{\text {th }}, 2012$; accepted January $29^{\text {th }}, 2012$

\begin{abstract}
African Cassava mosaic disease (ACMD) is the most severe and widespread disease caused by viruses limiting production of the crop in sub-Saharan Africa. The objective of the present study was to evaluate CMD incidence, severity, and gravity under different agro-environmental conditions. A total of 222 fields were surveyed in 23 different locations. All the farmers grow only local cassava varieties without applications of fertilizers. Overall, mean CMD incidences for all sites surveyed were 58.2\% and 51.7\%, in 2009 and 2010, respectively. Disease severity ranged from 2.4 to 3.1 on a scale of 1 to 5. Mean disease gravity varied from 29.7\% to 62\%, in 2010, and 2009, respectively. Detailed analysis of agronomic and environmental revealed no significant association between cassava stand locations, age, land topography and the development of CMD. Likewise intercropping practices and field topping did not affect the development of CMD in all the fields surveyed. There were significant differences in the number of white flies (Bemisia tabaci) per plant in 2009 and 2010, but no significant correlations between the number of B. tabaci per plant and CMD incidence, severity, and gravity was found. In most fields, CMD appears to originate mostly from unhealthy cassava cuttings used for planting.
\end{abstract}

Keywords: Cassava Mosaic Disease; Farmers’ Fields; Agro-Environmental Factors; Gandajika; DR-Congo

\section{Introduction}

Cassava (Manihot esculenta Crantz) is a major food crop for people living in the tropics where it represents the fourth major source of energy [1,2]. Its tuberous roots are the staple food of 800 million people in the Third World, which making it the sixth source of calories in food (Alves, [1,2]. Recognized as a plant tolerant to marginal soils and climatic conditions, cassava is usually grown as a subsistence crop by small farmers [2-5].

In the DR-Congo (DRC), cassava is both a source of food and income for about $70 \%$ of population. This crop is grown in more than $50 \%$ of arable land for food crops in the DR-Congo. In the savannah region of Gandajika where over $90 \%$ of the workforce depends on agriculture, maize, beans, and cassava are the main staple foods. But cassava production is affected by various diseases, par-

${ }^{*}$ Corresponding author. ticularly the cassava mosaic disease (CMD), which causes enormous yield losses in the field. This viral disease is caused by cassava mosaic geminiviruses (Family, Geminiviridae: Genus, Begomovirus) that is spread by the whitefly vector Bemisia tabaci (Gennadius). It infects cuttings used for planting a new field [6-11].

In DR-Congo, various strategies have been considered and applied by different research centers and programs to manage the CMD. Several genetically improved varieties resistant to the CMD adapted to local conditions and producing a high yield of tuberous roots have been developed and released in the region. However, the adoption of these varieties by farmers has been a challenge, because their selection criteria which include specific characteristics related to environmental conditions, organoleptic traits and marketability have been ignored. In addition, phytosanitary practices consisting in planting only disease free cuttings are not respected by most farmers. This 
is likely to result in an increase of CMD prevalence.

In general, several factors contribute to the emergence and the development of cassava diseases. They include cultural practices (weeding, ridging and topping), fertilizer use, origin and type of material planted, and cropping system, etc. $[2,12,13]$. It is therefore important to understand the agro-ecological conditions that may affect the epidemiology of a particular disease such as CMD in a region.

The objective of the present study is to evaluate the prevalence of CMD in a savannah region in the DRCongo and to characterize local agro-environmental factors that may affect CMD incidence, severity and gravity.

\section{Materials and Methods}

\subsection{Site Description and Field Sampling}

Epidemiological surveys were conducted in farmers' fields in Gandajika, (Eastern Kasaï-DR-Congo) in the growing seasons A of 2009 and 2010. The region falls within the Aw4 climate type according to Köppen classification characterized with 4 months of dry season (from mid-may to august) coupled with 8 months of rainy season, sometimes interrupted by a short dry season in January/February. Daily temperature averages $25^{\circ} \mathrm{C}$ and annual rainfall is close to $1500 \mathrm{~mm}$. Typically, Gandajika soils consist of a collection of sandy on clay sediment more often based on a shallow lateritic old slab. The adsorption complex is fairly well saturated and there are still some weatherable minerals.

A total of 222 farmers' fields were surveyed including 115 fields in season 2009 and 107 fields in 2010. Locations of fields surveyed are presented in Figure 1. Twenty-three sites across the Greater Gandajika region were sampled: 4 fields in Mpasu sanda, 17 fields in Mpemba nzeo, 14 fields in Kaniaka, 8 fields in Mulamba 2, 18 fields in Mande intérieur, 10 fields in Luanga, 10 fields in Nsona shabanza, 8 fields in Mpiana, 10 fields in Yamba, 8 fields in Bena cilewu, 10 fields in Mulamba 1, 10 fields in Kaseki, 7 fields in Kaniana, 9 fields in Mpiana basangana, 8 fields in Nsona bena Tshilumba, 4 fields in Tshioji, 10 fields in Kasumpata, 10 fields in Bena Tshilombo, 10 fields in Bakwa mulumba, 9 fields in Misombo, 10 fields in Mwanza ngudia, 8 fields in Nkuanya and 10 fields in Mpata.

\subsection{Incidence, Severity and Gravity of Cassava Mosaic Disease, and Number of B. tabaci per Plant}

The fields surveyed were selected randomly. In each stand, 30 cassava plants selected along two longitudinal transepts were analyzed [5]. CMD Incidence, severity and gravity were measured. Disease incidence was calculated by the percentage of plants with symptoms.

Severity was assessed using a scale of 1 to 5 described by Hahn 87 where 1 corresponds to an apparently healthy plant and 5 corresponds to severe mosaic symptom including leaf deformation. Gravity of CMD per plant was assessed by the percentage of leaves with symptoms. The number of B. tabaci per plant was counted on the top 5 younger leaves [5].

\subsection{Agro-Environmental Factors}

Agro-environmental characteristics of each field were determined. They included field location, type of farms (commercial vs. familial), origin and type of material planted, age of cassava stands, land topography, intercropping practice, crops mixed with cassava, use of fertilizer, topping application and presence of weed crops in the fields. Geographical coordinates of each site were recorded using a global position system (GPS; etrex Summit Garmin) and limit of the surveyed zone was represented on map (Figure 1) using ArcGIS 9 software.

\subsection{Data Analysis}

The experiment was unbalanced design with unequal replicates per site. The data for the CMD incidence and gravity were analyzed using SPSS 7.5 for Windows, with all data being transformed using a $\log 10$ transformation to achieve a normal distribution. Variance-ratio test was done with an assumption of data normality in the underlying population distributions of the data. ANOVA, followed by Tukey's HSD multiple comparison analysis, were performed to determine significant differences $(p<$ $0.05)$ among the sites. The means were separated by the least significant differences, L.S.D. at probability level of 0.05\%. The 2009 and 2010 data were compared using Tstudent tests.

\section{Results and Discussion}

\subsection{Incidence, Severity and Gravity of Cassava Mosaic Disease}

Cassava mosaic disease was present in all the sites surveyed during the two years. There were significant differences for disease incidences among sites for both years (Tables 1 and 2). In 2009, the highest CMD incidence (76.6\%) was observed in Mpiana, and the lowest incidence (38.6\%) in Mulamba 1. Overall, the mean incidences for all the sites surveyed were $58.2 \%$ and $51.7 \%$, in 2009 and 2010, respectively. In 2010, the highest incidence was recorded in Bakwa Mulumba (81.3\%) and the lowest of $28.3 \%$ in Bena Tshilombo.

In general disease severity was moderate in all sites 


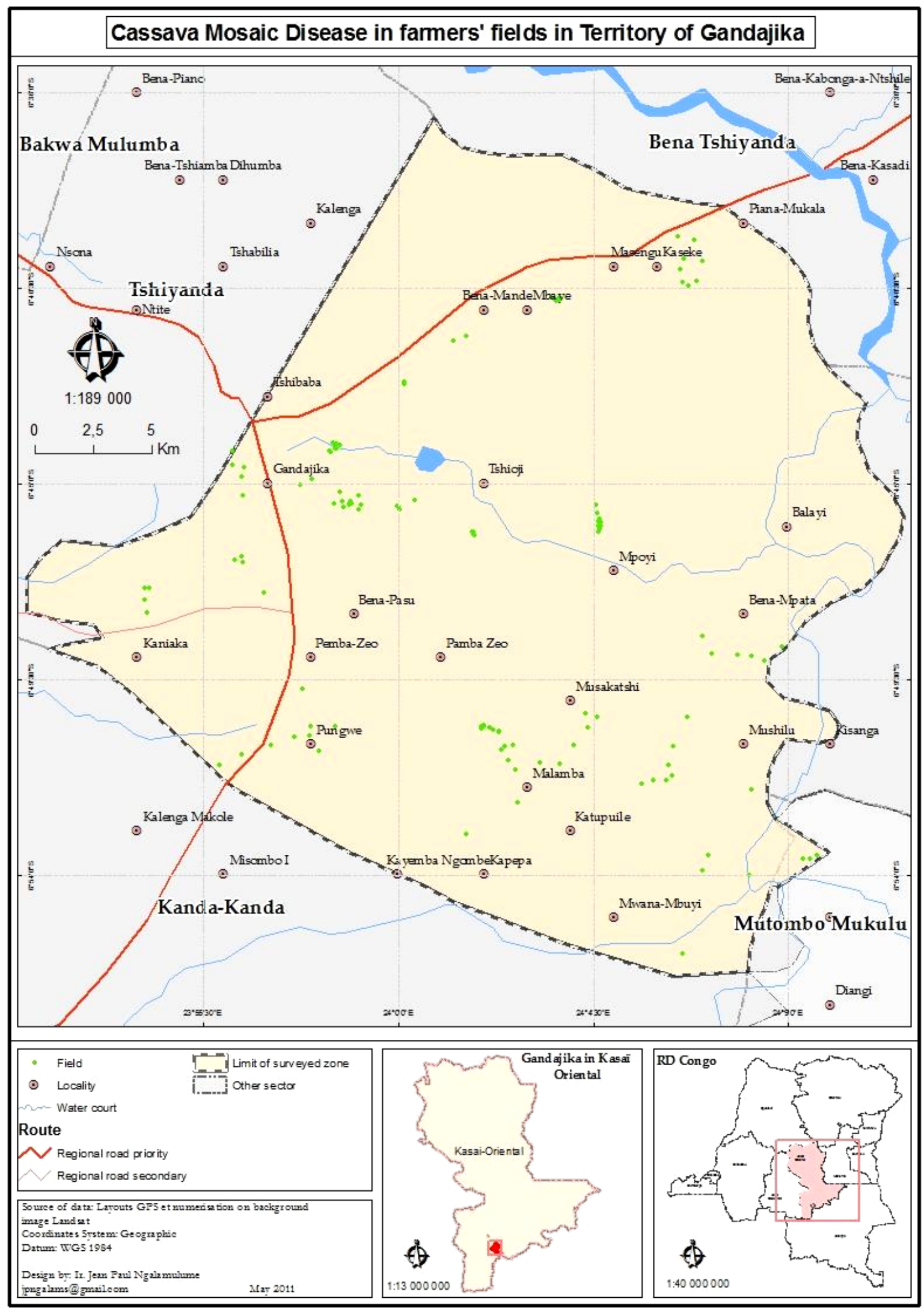

Figure 1. Map of Gandajika (DR-Congo) showing locations of farmers' fields studied. 
Table 1. Incidence (\%), severity and gravity (\%) of the Cassava mosaic disease, and number of whiteflies (Bemisia tabaci) per sites in 2009 in Gandajika (Eastern Kasai-DR-Congo).

\begin{tabular}{|c|c|c|c|c|c|}
\hline Growing season & Sites & Incidence & Severity $(1-5)$ & Gravity & Number of B. tabaci per plant \\
\hline \multirow{12}{*}{ A 2009} & Mpasu sanda & 46.6 & 3.0 & 39.7 & 0.45 \\
\hline & Mpemba nzeo & 61.7 & 2.7 & 53.6 & 0.84 \\
\hline & Kaniaka & 71.1 & 2.9 & 66.2 & 1.16 \\
\hline & Mulamba 2 & 54.1 & 3.1 & 43.3 & 0.67 \\
\hline & Mande intérieur & 53.3 & 2.9 & 49.9 & 0.40 \\
\hline & Luanga & 65.6 & 2.7 & 59.2 & 0.34 \\
\hline & Nsona shabanza & 61.6 & 2.9 & 58.1 & 0.42 \\
\hline & Mpiana & 76.6 & 2.6 & 63.4 & 0.6 \\
\hline & Yamba & 53.3 & 2.7 & 47.7 & 0.59 \\
\hline & Bena Cilewu & 57.9 & 2.9 & 56.0 & 0.79 \\
\hline & Mean $\pm \mathbf{S E}$ & $58.3 \pm 3.25$ & $2.8 \pm 0.05$ & $52.0 \pm 3.02$ & $\mathbf{0 . 6 1} \pm \mathbf{0 . 0 7}$ \\
\hline & $\operatorname{LSD}(P \geq 0.05)$ & 8.9 & 0.4 & 7.8 & 0.5 \\
\hline
\end{tabular}

SE: Standard Error.

Table 2. Incidence (\%), severity and gravity (\%) of the CMD, and number of whiteflies (Bemisia tabaci) per locality in 2010 in Gandajika (Eastern Kasai-DR-Congo).

\begin{tabular}{|c|c|c|c|c|c|}
\hline Growing season & Sites & Incidence & Severity $(1-5)$ & Gravity & Number of B. tabaci per plant \\
\hline \multirow{14}{*}{ A 2010} & Kaseki & 40.6 & 2.4 & 27.5 & 0.97 \\
\hline & Kaniana & 49.0 & 2.6 & 39.5 & 0.84 \\
\hline & Mpiana basangana & 46.2 & 2.7 & 23.6 & 1.12 \\
\hline & Nsona bena Tshilumba & 58.7 & 2.7 & 41.4 & 1.42 \\
\hline & Tshioji & 44.1 & 3.0 & 25.5 & 0.67 \\
\hline & Kasumpata & 37.6 & 2.7 & 22.6 & 3.55 \\
\hline & Bena tshilombo & 28.3 & 2.8 & 17.6 & 1.03 \\
\hline & Bakwa mulumba & 81.3 & 2.7 & 36.9 & 1.91 \\
\hline & Misombo & 45.9 & 2.8 & 21.1 & 7.03 \\
\hline & Mwanza ngudia & 49.3 & 2.5 & 18.4 & 2.05 \\
\hline & Nkuanya & 70.8 & 2.8 & 36.8 & 2.80 \\
\hline & Mpata & 68.6 & 2.8 & 45.0 & 5.61 \\
\hline & Mean \pm SE & $51.7 \pm 4.41$ & $2.7 \pm 0.04$ & $29.7 \pm 2.78$ & $2.4 \pm \mathbf{0 . 5 8}$ \\
\hline & $\operatorname{LSD}(P \geq 0.05)$ & 9.1 & 0.4 & 6.9 & 1.2 \\
\hline
\end{tabular}

SE: Standard Error.

ranging from 2.6 to 3.1 on a scale of 1 to 5 . Overall mean severity for all sites was 2.8 in 2009, with the highest severity (3.1) recorded in Mulamba 2 and the lowest of 2.6 in Mulamba 1. In 2010, CMD severity varied from 2.4 in Kaseki to 3.0 in Tshioji. The overall mean severity for all sites was 2.7.

Disease gravities were significantly different among sites for each year (Tables 1 and 2). In 2009, the highest
CMD gravity (66.2\%) was observed in Kaniaka with the lowest value recorded in Mulamba 1. Overall mean disease gravity was 52\%. The mean disease gravity in 2010 was $29.6 \%$, with the highest gravity $(45.0 \%)$ recorded in Mpata and the lowest value of $17.6 \%$ observed in Bena Tshilombo.

Statistical analysis revealed that number of $B$. tabaci per plant was not significantly different $(P>0.05)$ among 
sites for each year. The highest number of B. tabaci per plant in 2009 was 1.16 observed in Kaniaka, and the lowest number of B. tabaci of 0.34 in Luanga. Overall, mean for all sites in 2009 was 0.61 whitefly per plant. In 2010, the number of $B$. tabaci per plant varied from 0.67 observed in Tshioji to 7.03 in Misombo. Mean number of whitefly was 2.4 in 2010 (Tables 1 and 2). More importantly, there were no significant correlations between the number of B. tabaci per plant and CMD incidence, severity, and gravity (Table 3 ).

\subsection{Agro-Environmental Factors}

Field location: Fields surveyed were established either in savannah or around the huts. Most of cassava crop in the region were grown in savannah (97\%) while only 3\% were planted around the huts. The study revealed that all the farmers' fields surveyed in Gandajika region are of family-types. No commercial farm was found in any site surveyed. This suggests that cassava is grown primarily to meet household needs.

Genetic materials: Farmers used only local cassava varieties and no genetically improved cassava variety was grown in any site. This confirms that the adoption of new varieties is still very difficult despite effort to promote them in different communities.

Age of cassava stands: For the present study, cassava fields were classified into three groups based on the date of plantation. The first group included one to six month old cassava stands, the second field group with 7 to 12 months old cassava, and the last group with cassava stands of over 12 months old (Table 4). The results of the survey revealed that $62 \%$ of cassava fields were one to six month old, $36 \%$ were 7 to 12 month old, and $2 \%$ were older than 12 months. Details of the distribution of cassava stands grouped by dates of plantation are described in Table 4.

Land topography: The farmers' fields were either on flat ground or on hillslope lands. Analysis of data reported in Table 4 revealed that $79 \%$ of cassava crops in the region were grown on flat lands and $21 \%$ on hillslope. The incidence and gravity of CMD in Bena Cilewu on hillslope lands were not significantly different from data observed in Mpemba Nzewu where $100 \%$ of cassava crops were grown on flat lands. These values were higher than those observed in Bena Tshilombo, Kaseki and Mpasu Sanda where also all the Cassava fields were found on flat lands.

Intercropping practice: was also analyzed in all the targeted sites. In general $45 \%$ of cassava stands were grown in association with other crops. Data presented in Table 4 revealed that $83 \%$ of cassava crops were grown in mixed stands with cereal (mostly maize), $16 \%$ with legumes (beans, cowpeas or soybeans), and 1\% with vegetable crops (Amaranthus spp., sweet potatoes etc.). There was great variability among sites for intercropping practices. For example, intercropping was practiced in $100 \%$ of cassava stands in Mande, Mpiana, Yamba and Mulamba 1, in $37.5 \%$ of stands in Nsona, Bena Tshilumba and Bena Cilewu, and in 0\% of fields in Tshioji, Kasumpata, Bena Tshilombo, Bakwa Mulumba, Misomba, Muanza Ngudia, Nkuanya, and Mpata. In addition, Cassava was associated with legume in $67 \%$ of fields in Bena Cilewu and only in 5\% in Yamba and Mulamba 1. Cassava mixed with maize was found in all the cassava stands in Kaseki and only $33 \%$ in Bena Cilewu. Association of cassava with vegetable crop was observed only in Luanga, where it represented a frequency of $12.5 \%$ of stands. Overall, there was no association between intercropping practices and the levels of CMD incidence, severity and gravity.

Fertilizer application and field topping: The survey of the 23 sites revealed that no single cassava stand was fertilized during the observation period. This confirms that low input agriculture is practiced in small family farms throughout the region. The applications of chemical fertilizers in other studies have been associated to an increase of CMD incidence, severity and gravity in several field trials $[14,15]$.

It should be pointed out that field topping was practiced in $40 \%$ of cassava stands before or during growing season. Field topping was observed in all the cassava stands in Mwanza ngudia while no topping was reported in Bena Cilewu, Tshioji and Mulamba 1. In other sites, field topping varied from $10 \%$ to $90 \%$ of cassava stands.

Weed crops: Results reported in Table 4 showed that, except for fields located in Tshioji, weed crops were

Table 3. Correlation coefficients between the number of whiteflies (Bemisia tabaci) per plant and cassava mosaic disease Incidence, severity, and gravity.

\begin{tabular}{cccc}
\hline Growing Season & $\begin{array}{c}\text { Correlation between incidence } \\
\text { and Number of B. tabaci per } \\
\text { plant }\end{array}$ & $\begin{array}{c}\text { Correlation between Severity } \\
(\mathbf{1} \text { - 5) and Number of B. tabaci } \\
\text { per plant }\end{array}$ & $\begin{array}{c}\text { Correlation between gravity } \\
\text { and Number of B. tabaci per } \\
\text { plant }\end{array}$ \\
\hline A 2009 & 0.359 & 0.104 & 0.377 \\
A 2010 & 0.206 & 0.235 & 0.058 \\
A 2009 \& A 2010 & 0.024 & 0.043 & -0.371 \\
\hline
\end{tabular}




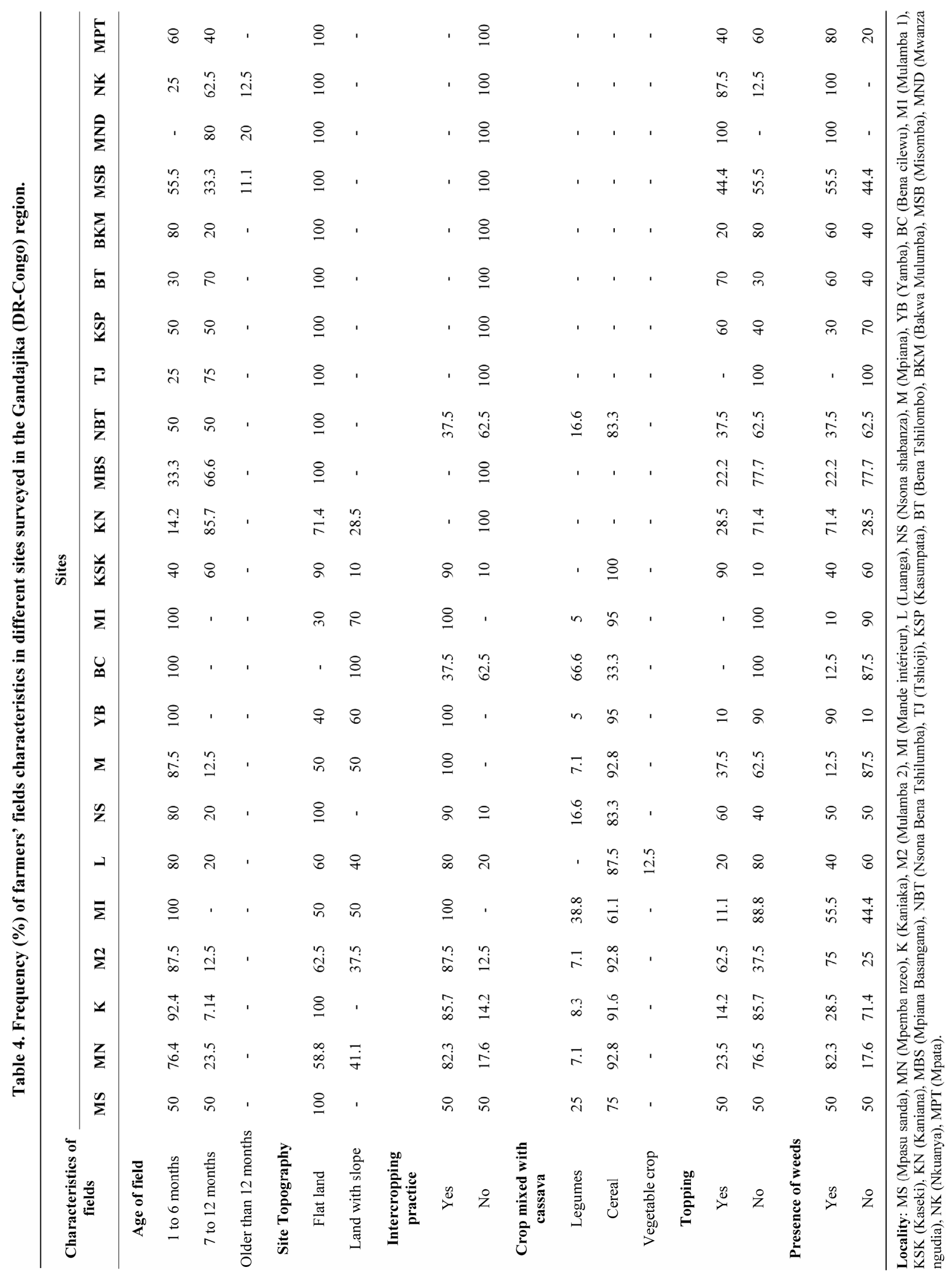


found in all sites surveyed regardless of the age of cassava stands. Weed crops were present in all the fields in Muanza Ngudia and Nkuanya. In general 51\% of the 122 fields visited within the region were not controlling weed crops in cassava stands. On close observation, all cassava stands with a high density of weed crops showed a high level of CMD incidence, but the gravity of the disease was not associated with weed crop abundance.

White flies (B. tabaci): white flies are the main vectors of CMV. In the present study, there were significant differences in the number of white flies per plant in 2009 and 2010. The mean number of whiteflies per plant was four times higher in 2010 compared to 2009 while the CMD incidence was 58\% in 2009 and 52\% in 2010. These confirm the absence of any association between the number of $B$. tabaci per plant and CMD incidence, severity, and gravity. The correlation values between the number of white flies (B. tabaci) and the CMD incidence, severity and gravity were $0.024,-0.043$, and -0.371 , respectively for combined 2009 and 2010 data. Details correlations between these disease parameters and the number of B. tabaci for each year are described in Table 4.

The results of the present study revealed that cassava mosaic disease (CMD) are spread throughout all the sites within Gandajika agricultural region. Overall, CMD incidence, severity and gravity varied from site to site. Similar cases of variability have been reported by several authors in other African countries. Data reported by Legg and Thresh [16] and Legg et al. [17] also revealed variability of CMD incidence among locations and varieties. In Nigeria, Ariyo et al. [18] reported that severity of CMD varied with ecozones where different cassava varieties were planted. The gravity of symptoms observed in the present study varied also among leaves of a same plant.

According to Hillocks and Thresh [10] variability in the pathological variables of CMD is often attributed to several factors such as different strains of virus, susceptibility and age of the host plant, and environmental factors such as soil fertility, soil moisture, solar radiation and temperature. It should be pointed out that most fields surveyed were within a $100 \mathrm{~km}$ radius. Thus no significant variation for rainfalls and temperatures among sites was observed. These climatic factors did not play any role in variability of CMD incidence, severity, and gravity in the targeted region. The number of $B$. tabaci per plant varied also from site to site. This variability appears to be related to varietal preference by $B$. tabaci as suggested by Sserubombwe et al. [19].

Detailed analysis of agronomic and site characterization showed no association between agro-environmental factors and the development of CMD. In fact, site loca- tions, farm type, age of cassava stands, land topography, and use of fertilizers did not affect the expression and the development of CMD. It is likely that the type and the origin of cassava cuttings used for planting are the most important factors for CMD development in farmers' fields. Most farmers collect cassava planting cuttings in random without specific care for the presence of CMD in plants. The presence of weed crops might play a limited role in the spread of the disease in farmer's field as natural hosts of the virus mosaic disease

\section{Conclusion}

All varieties planted in farmers' fields in all sites were local types. This is an indication that there is a real need to facilitate access to genetically improved planting materials in rural zone of Gandajika. Access to disease free cuttings from local varieties should be a priority in short term. A large-scale, distribution and promotion programs of resistant plant material from genetically improved and adapted varieties represent important strategies to control CMD in long term within the targeted region. Molecular analysis of the CMD virus is being conducted to determine the diversity of viral strains of CMD prevalent in this region of DRC.

\section{Acknowledgements}

We express our gratitude to the Canadian International Development Agency (through PUCD collaborative project involving Caritas Congo-UNIKIN-Laurentian University) and Project KIN 01 (Molecular Biology, CUICUD) for financial support. Special thanks to Ir. Jean Paul Ngalamulume for designing the map, to siter Nicole Ntumba (Sister Theresian-Gandajika) and Caritas Mbuji Mayi for facilitating field studies.

\section{REFERENCES}

[1] G. H. De Bruinjn and C. O. Fresco, "The Importance of Cassava in World Food Production," Netherland Journal of Agricultural Sciences, Vol. 37, No. 5, 1989, pp. 21-34.

[2] A. A. C. Alves, "Cassava Botany and Physiology,” In: R. J. Hillocks, J. M. Thresh and A. C. Bellotti, Eds., Cassava: Biology, Production and Utilization, CAB International, Wallingford, 2002, pp. 67-89. doi:10.1079/9780851995243.0067

[3] J. C. Lozano, "Overview of Integrated Control of Cassava Diseases,” Fitopatologia Brasileira, Vol. 17, 1992, pp. 18-22.

[4] J. M. Thresh, G. W. Otim-Nape, J. P. Legg and D. Fargette, "African Cassava Mosaic Virus Disease: The Magnitude of the Problem," African Journal of Root and Tuber Crops, Vol. 2, No. 1, 1997, pp. 13-19.

[5] P. Ntawuruhunga, G. Okao-Okuja, A. Bembe, M. Obambi, 
J. C. A. Mvila and J. P. Legg, "Incidence and Severity of Cassava Mosaic Disease in the Republic of Congo," African Crop Science Journal, Vol. 15, No. 1, 2007, pp. 1-9.

[6] B. R. Harrison, H. Barker, K. R. Bock, J. Guthrie, G. Meredith and M. Atkinson, "Plant Viruses with Circular Single Stranded DNA,” Nature London, Vol. 270, 1977, pp. 760-762. doi:10.1038/270760a0

[7] S. K. Hahn, "Breeding Cassava for Resistance to Cassava Mosaic Disease,” Euphytica, Vol. 29, No. 2, 1980, pp. 673-683. doi:10.1007/BF00025127

[8] D. Fargette, J. C. Thouvenel and C. Fauquet, "Virus Content of Leaves of Cassava Infected by African Cassava Mosaic Virus," Annals of Applied Biology, Vol. 110, No. 1, 1986, pp. 65-73. doi:10.1111/j.1744-7348.1987.tb03233.x

[9] J. Dubern, "Transmission of African Cassava Mosaic Geminivirus by the Whitefly (Bemisia tabaci),” Tropical Science, Vol. 34, 1994, pp. 82-91.

[10] R. J. Hillocks and J. M. Thresh, "Cassava Mosaic and Cassava Brown Streak Virus Diseases in Africa: A Comparative Guide to Symptoms and Etiologies," Roots, Vol. 7, No. 1, 2000, pp. 1-8.

[11] L. A. Calvert and J. M. Thresh, "The Viruses and Virus Diseases of Cassava,” In: R. J. Hillocks, J. M. Thresh and A. C. Bellotti, Eds., Cassava: Biology, Production and Utilization, CAB International, Wallingford, 2002, pp. 237-260. doi:10.1079/9780851995243.0237

[12] J. C. Zadock, "On the Conceptual Basis of Crop Loss Assessment: The Threshold Theory," Annual Review of Phytopathology, Vol. 23, No. 1, 1985, pp. 455-473. doi:10.1146/annurev.py.23.090185.002323

[13] A. C. Bellotti, L. Smith and S. L. Lapointe, "Recent Advances in Cassava Pest Management," Annual Review of Entomology, Vol. 44, 1999, pp. 343-370.

\section{doi:10.1146/annurev.ento.44.1.343}

[14] P. Sseruwagi, G. W. Otim-Nape, D. S .O. Osiru and J. M. Thresh, "Influence of NPK Fertiliser on Populations of the Whitefly Vector and Incidence of Cassava Mosaic Virus Disease," African Crop Sciences Journal, Vol. 11, No. 3, 2003, pp. 171-179.

[15] M. Muengula-Manyi, K. K. Nkongolo, C. Bragard, P. Tshilenge-Djim, S. Winter and A. Kalonji-Mbuyi, "Effect of NPK Fertilization on Cassava Mosaic Disease Expression in a Sub-Saharan African Region,” International Journal of Agricultural Research, 2011, Article in Press.

[16] J. P. Legg and J. M. Thresh, "Cassava Mosaic Virus Disease in East Africa: A Dynamic Disease in a Changing Environment," Virus Research, Vol. 71, No. 1-2, 2000, pp. 135-149. doi:10.1016/S0168-1702(00)00194-5

[17] J. P. Legg, B. Owor, P. Sseruwagi and J. Ndunguru, “Cassava Mosaic Virus Disease in East and Central Africa: Epidemiology and Management of Regional Pandemic," Advances in Virus Research, Vol. 67, 2006, pp. 355-418. doi:10.1016/S0065-3527(06)67010-3

[18] O. A. Ariyo, A. G. O. Dixon and G. I. Atiri, "Whitefly Bemisia tabaci (Homoptera: Aleyrodidae) Infestation on Cassava Genotypes Grown at Different Ecozones in Nigeria,” Journal of Economic Entomolgy, Vol. 98, No. 2, 2005, pp. 611-617. doi:10.1603/0022-0493-98.2.611

[19] W. S. Sserubombwe, J. M. Thresh, G. W. Otim-Nape and D. S. O. Osiru, "Progress of Cassava Mosaic Virus Disease and Whitefly Vector Populations in Single and Mixed Stands of Four Cassava Varieties Grown under Epidemic Conditions in Uganda," Annals of Applied Biology, Vol. 138, No. 2, 2001, pp. 161-170. doi:10.1111/j.1744-7348.2001.tb00098.x 